\title{
Biofiltration of Methane Fugitive Emissions from Landfills Using Scum from Municipal Wastewater Treatment Plants (Wwtp) as Alternative Substrate
}

Waldir Nagel Schirmer ( $\nabla$ wanasch@hotmail.com )

UNICENTRO: Universidade Estadual do Centro-Oeste https://orcid.org/0000-0001-9475-3588

\section{Erivelton César Stroparo}

UNICENTRO: Universidade Estadual do Centro-Oeste

\section{Marlon André Capanema}

IFG: Instituto Federal Goiano

Douglas Luiz Mazur

UNICENTRO: Universidade Estadual do Centro-Oeste

José Fernando Thomé Jucá

UFPE: Universidade Federal de Pernambuco

Kelly Geronazzo Martins

UNICENTRO: Universidade Estadual do Centro-Oeste

\section{Research Article}

Keywords: biofilter, biogas, methane oxidation, renewable energies, solid wastes valorisation

Posted Date: September 16th, 2021

DOI: https://doi.org/10.21203/rs.3.rs-790129/v1

License: (c) (i) This work is licensed under a Creative Commons Attribution 4.0 International License. Read Full License 


\section{Abstract}

Biofilters have been recognized as key technology in the mitigation of greenhouse gases (GHG) emitted by landfills. This study aimed to evaluate the methane (an important GHG) oxidation efficiencies of two experimental biofilters at the municipal landfill of Guarapuava (Brazil) under normal conditions (control column), just using landfill cover soil with low organic matter content, and improved, exploiting dried scum from municipal wastewater treatment plant (SWWTP) mixed with the cover soil (enriched column, with a high organic matter content). The influence of parameters such as the methane inlet loading rates (22 and $\left.44 \mathrm{~g}_{\mathrm{CH} 4} \cdot \mathrm{m}^{-2} \cdot \mathrm{d}^{-1}\right)$, temperatures, methane concentration in the raw biogas, carbon/nitrogen ratio and moisture content of the packing materials on the oxidation of methane was also evaluated during 25 campaigns. The campaigns with the lowest methane loading rates applied to the biofilters showed the best methane oxidation efficiencies ( $98.4 \%$ and $89.5 \%$ in the enriched and control columns, respectively) as compared to campaigns with a higher load $(92.6 \%$ and $82.6 \%$ in the enriched and control columns, respectively). In addition to the loading rates, the methane oxidation efficiencies were highly influenced by the organic matter content and $\mathrm{C} / \mathrm{N}$ ratio of the packing materials evaluated.

\section{Statement Of Novelty}

Biotic systems have been successfully applied in the mitigation of methane in landfill cover layers. However, most of the documented studies in the technical literature address the use of bio-based systems in countries with temperate climates and/or in landfills with some recovery system of the landfill gas (LFG). Similar studies in developing countries and tropical climates using organic residues in the substrate layer are scarce and, at the same time, extremely important, since there are practically no landfills with biogas recovery systems in these countries, which can further enhance fugitive emissions through the cover layer.

\section{Introduction}

Landfills are still the principal final destination for municipal solid wastes (MSW) in the majority of countries, be they developing countries such as Brazil or even developed countries. The waste management sector, especially landfills, is amongst the main anthropogenic methane (an important greenhouse gas GHG) emission sources into the atmosphere. Studies indicate that in 2030 landfills will be responsible for up to $10 \%$ of the total methane emissions [1, 2]. The atmospheric emissions from landfills depend on the amount of biogas flared or recovered for energy purposes. Nevertheless, even with some form of mitigation or recovery, a good part of the methane generated in the waste mass escapes to the atmosphere via the cover layer as fugitive emissions [3-5]. The gaseous emissions through the cover layer can vary a lot, both temporally and spatially, and can occur for various decades, even after closure of the landfill [6-9]. This spatial variability is the result of the enormous heterogeneity of waste mass and of the cover layer in terms of the degree of compaction, soil texture, porosity, fissures, etc., such that the methane emissions through the cover layer can present differences to various orders of magnitude, from 0.0002 to $4000 \mathrm{~g} \mathrm{CH}_{4} \cdot \mathrm{m}^{-2} \cdot \mathrm{d}^{-1}$ [10-12]. 
Various bio-based systems have evaluated the properties of methanotrophic bacteria in oxidizing methane in optimised landfill covers, with or without biogas collection systems, as a function of their relatively low cost and elevated treatment efficiency. Biotarps, biocovers, biowindows and biofilters are amongst the treatment systems most reported in the technical literature and have been widely used to mitigate GHG [5, $6,13-19]$, principally in small, old landfills, where energy recovery is not technically or economically viable $[18,20]$.

For example, biocovers and biofilters have been recognized as key technologies in the waste management sector to mitigate GHG from landfills [21]. In the case of biocovers, the final cover is enriched with organic substrates such as sewage sludge and compost, to support the methanotrophic microorganisms responsible for methane oxidation. In the case of biofilters, the methanotrophic microorganisms are supported on packed bed columns (fixed-bed reactors) and the biogas provided to the biological filter either actively or passively (depending on whether the LFG are collected using a pumping system or not), generally operating in an up-flow mode $[14,16,18,19,22]$. This GHG treatment system is indicated for small-scale landfills or even landfills with an active gas collection system. As compared to biocovers, biofilters provide a better control of the methane oxidation process, since their construction and operation mode allow for minimization of interference of the process by the atmospheric conditions [5,23]. Since it is a biological process, various parameters influence the performance of the treatment, some of which are inherent to the filter bed (such as $\mathrm{pH}$, temperature, moisture content, nutrient contents and porosity), environmental conditions (such as ambient temperature) and operational conditions (loading rate, residence time, gas flow direction, gas concentration, etc.). Thus, various researchers have tested the most varied substrate materials (compost, sewage sludge, sand, garden waste, wood chips, expanded clay, etc. and their mixtures with the cover soil), biogas loading rates, climatic conditions, etc., always with the goal of studying and optimizing the methane oxidizing conditions in the landfill cover layer $[6,13,24-27]$.

The relationship between the methane removal efficiencies and parameters such as the organic matter and moisture contents of the packing material, and also of the environmental and packing bed temperatures have been widely documented in the technical literature. Substrates rich in organic matter, as well as being a carbon source, are an important source of micro and macronutrients for the cell metabolism of the methanotrophic microorganisms [1, 28, 29] Franqueto et al. [28] evaluated the performance of a biocover constructed at the Guarapuava landfill (southern Brazil) and compared it to a local landfill cover soil with a low organic matter content $(\approx 0.4 \%)$. The enriched biocover consisted of a mixture of landfill cover soil plus compost, with a final organic matter content of $4.5 \%$. In the 16 monitoring campaigns of $\mathrm{CH}_{4}$ surface fluxes, values of 20 and $34 \mathrm{~g} \cdot \mathrm{m}^{-2} \cdot \mathrm{d}^{-1}$ were obtained at the surfaces of the enriched and control areas, respectively, or mean methane oxidation efficiencies of 80 and $42 \%$ (in the same order). The better performance of the enriched area was attributed to the greater amount of organic matter in the medium and, hence, a greater amount of nutrients for the methanotrophic population.

Control of the moisture content of the medium is essential for the performance of the biofilters. An excessive water content prejudices the mass transference of oxygen and contaminant in the gaseous phase to the biofilm, especially when dealing with low solubility compounds such as methane in an aqueous medium. In addition, gas circulation through the packing material may be reduced due to 
substrate pore blocking, thus increasing the pressure drop in the filter bed. On the other hand, a moisture content below the recommended value compromises, for example, the provision of nutrients necessary for the methanotrophic activity $[13,15,19,30,31]$. The literature has mentioned different optimal moisture content ranges for methane oxidation, with values of $20-35 \%$ [32], 30-50\% [33], 66\% [34] and $11-32 \%$ [20], etc., depending on the operational conditions and filter bed composition.

Many papers have reported a strong correlation between oxidation efficiency and temperature $[19,26,35$, 36]. Although the majority of these studies have found a tendency to increase the methane removal efficiency with increase in temperature of the medium, and, in the same way, a reduction in the removal efficiency with a decrease in temperature, this behaviour cannot be considered as a rule. Depending on the study conditions, methane bio-oxidation efficiencies above $80 \%$ can be obtained even under low environmental temperature conditions $[37,38]$.

Almost all the studies documented in the literature are about the use of bio-based systems in temperate climates and/or landfills with some form of LFG exploitation. Similar studies in developing or tropical countries (such as Brazil) using organic residues in the cover layer are rare, and, at the same time, extremely important, since landfills with biogas recovery systems are practically non-existent in these countries, which could potentiate fugitive emissions through the cover layer even more [28]. In addition, the climatic conditions in tropical countries, as also the characteristics of the MSW (with a greater amount of organic matter) require specific studies. Given their good properties as an amendment to the cover soil in the oxidation of methane, compost has been the substrate most used by researchers both on a laboratory scale and in the field. Nevertheless, in practice, since the use of the compost could be quite limited in field scale applications due to limited availability throughout the entire operational period of the landfill, the search for alternative materials with equally good characteristics as an amendment to the cover soil, has become a major concern of researchers [18]. Scum is one of the main solid by-products produced during the steps of municipal wastewater treatments, and as such represents a great environmental liability for the wastewater treatment plants (WWTP), landfills frequently being its final destination, with no exploitation of this residue $[39,40]$. Since it presents high organic matter and nutrient contents, and has already been sent to the landfill, scum could be evaluated as a potential amendment, thus enhancing its disposition in the landfill.

Thus the objective of the present study was to evaluate, using different loading rate conditions, the influence of variables such as environmental temperature (throughout the four seasons of the year), and the temperature and moisture content of the packing material on the methane oxidation efficiency in two columns (biofilters) under normal (just using landfill cover soil) and improved, using dried scum from municipal WWTP mixed with the cover soil, so as to raise the organic matter content of the biofilter.

\section{Material And Methods}

\section{Characterization of the study location and experimental setup}

The experiment was installed at the landfill of the municipality of Guarapuava (Paraná State, southern Brazil), in order to maintain the environmental conditions of the locality and the original composition of the 
LFG. The landfill started operating in 2011 [41] and stopped in the first semester of 2021. Until it stopped operating, the landfill served a population of 182,644 inhabitants (estimate made in 2020 according to the Brazilian Institute of Geography and Statistics - [42]) and received an average of @102 t/d of MSW (personal communication from technical staff, Guarapuava Municipal Landfill). It had no biogas recovery or energy valorisation system, only flaring, representing the conditions of the majority of landfills in developing countries.

Two biofilters were installed at the landfill in an area with a four-year-old final cover, and were monitored between October (2017) and September (2018) with a total of 25 campaigns. The seasons are well defined in southern Brazil, presenting hot summers and cold winters. During the 12 months of monitoring, the minimum mean daily temperature in Guarapuava was $6.9^{\circ} \mathrm{C}$ (winter of 2018) and the maximum $25.0^{\circ} \mathrm{C}$ (in the spring of 2018) [43]. Each biofilter consisted of a stainless-steel column, $1.0 \mathrm{~m}$ high by $0.6 \mathrm{~m}$ in diameter, thermally insulated on the outside by a $20 \mathrm{~cm}$ thick soil layer (only the top of the filters remained exposed to the environmental temperature). A $3.0 \mathrm{~cm}$ layer of \#2 gravel was placed under the packing beds to improve biogas distribution at the bottom of the biofilters (gas distribution layer - GDL). The biofilters were passively fed with biogas in the upflow mode from a vertical drain. Six sampling ports with rubber septa were installed throughout the height of the two columns to sample the gases (Figure 1). Samples of raw biogas and biogas from the column headspace were sampled from the lowest and highest sampling ports, respectively. The 4 central sampling ports were in contact with the filter media (installed at $12 \mathrm{~cm}, 24$ $\mathrm{cm}, 36 \mathrm{~cm}$ and $48 \mathrm{~cm}$ from the bottom of the packing material).

Table 1 shows the details of the two packing materials (enriched and control beds), both with a height of 60 $\mathrm{cm}$ above the GDL, used to evaluate the performance of the dried scum from the municipal wastewater treatment plant (SWWTP) mixed with the cover soil (enriched column) as the filter bed for methane oxidation, compared to the conventional cover soil (control column). The biofilters were maintained in a covered location throughout the monitoring period, and manually watered after each campaign so as to maintain moisture conditions favourable for microbial activity and avoid desiccation of the filter bed, avoiding the formation of cracks that could be preferential pathways for the biogas within the packing material.

Table 1 Biofilters composition.

\begin{tabular}{|c|c|c|c|}
\hline & Bed height $(\mathrm{cm})$ & Substrate & Organic matter (\%) \\
\hline \multirow{3}{*}{ Enriched column } & Highest $15 \mathrm{~cm}$ & Sandy clayey silt ${ }^{(1)}+$ SWWTP & $@ 4.5$ \\
\hline & Lowest $45 \mathrm{~cm}$ & Sandy clayey silt & $@ 0.5$ \\
\hline & 3 & GDL: \#02 gravel & \\
\hline \multirow[t]{2}{*}{ Control Column } & 60 & Sandy clayey silt & @0.5 \\
\hline & 3 & GDL: \#02 gravel & \\
\hline
\end{tabular}

(1) Characteristic of the original landfill soil 


\section{Characterization of the packing materials}

In addition to determining the organic matter contents (method described in Cantarella et al. [44]) of the landfill cover soil and of the mixture with SWWTP, as reported in Table 1, the parameters of the total carbon [45] and total nitrogen [46] contents and of the $\mathrm{pH}$ value [47] of the packing materials were determined at the start (October/2017) and end (September/2018) of the experiment. All the samples were removed from the first $10 \mathrm{~cm}$ of the filter beds.

A prior characterization of the scum from a WWTP in the same city as the landfill identified the following compounds and concentrations [48]: total organic carbon @24.3\%; phosphorous @0.09\%; nitrogen (Kjeldahl) @3,300 mg.kg-1; potassium @0.021\%; micronutrients (mg. $\left.\mathrm{kg}^{-1} \mathrm{TS}\right)$ : Cu @66, Mo <10, Ni @40, Zn @126 (mean values of 5 samples). Although generated in wastewater treatment plants, scum is considered as a solid residual by-product, and consequently, most of the scum produced in the anaerobic sewage treatment of the WWTPs of the State of Paraná is destined for landfills.

\section{Monitoring and performance of the biofilters}

The influence of variation in the methane loading rate on the methane removal efficiency was verified in this study. Considering that: (a) we found no registers concerning the values for methane loading rates as applied to cover layers in Brazilian landfills; (b) the average methane loading rates applied to cover layers in landfills in the USA and Canada with gas collection systems are $28 \mathrm{~g}_{\mathrm{CH} 4} \cdot \mathrm{m}^{-2} \cdot \mathrm{d}^{-1}$ [35]; and (c) the loading rate exerted under the cover layer in landfills with no active biogas collection system (as in the landfill evaluated) can vary greatly, and can be higher than those exerted in landfills with collection systems; considering these premises, the authors judged it reasonable to adopt inlet methane loading rates of @22 $\mathrm{g}_{\mathrm{CH} 4} \cdot \mathrm{m}^{-2} \cdot \mathrm{d}^{-1}$ (loading 1, with 13 campaigns) and @44 $\mathrm{g}_{\mathrm{CH} 4} \cdot \mathrm{m}^{-2} \cdot \mathrm{d}^{-1}$ (loading 2, with 12 campaigns), under standard temperature and pressure (STP) conditions.

Before starting a monitoring period, biogas was injected into the two biofilters during 40 days with a loading rate of @22 $\mathrm{g}_{\mathrm{CH} 4} \cdot \mathrm{m}^{-2} \cdot \mathrm{d}^{-1}$ to allow acclimatation of the methanotrophic population. The flowrates were measured periodically using soap bubble flowmeters and adjusted to maintain these values during monitoring of the biofilters.

Although the water volume added to the two biofilters was the same, it varied greatly throughout the campaigns as a function of the climatic conditions that dictated whether the filter beds dried to a greater or lesser extent. Water content probes (Decagon ECH2O CE-5) were placed $10 \mathrm{~cm}$ from the surface and mercury thermometers at 10 and $40 \mathrm{~cm}$ from the surface of the two beds. The moisture content and temperature were measured at the start of each campaign (water was added to the columns at the end of each campaign). The mean environmental temperatures during the days of the campaigns were obtained from the Paraná Rural Development Institute [43]. 
The biofilter performances were evaluated considering the methane oxidation efficiency throughout the vertical profile of the two columns. Raw biogas was sampled at the base of each biofilter (lower sampling port - Figure 1) whilst the gaseous sample from the headspace (upper sampling port - Figure 1) was sampled after capping the columns and reaching steady state. The gases were sampled using a 60-mL syringe and immediately analysed in a Columbus Instruments portable biogas meter with infrared sensors to detect methane $\left(\mathrm{CH}_{4}\right)$ and carbon dioxide $\left(\mathrm{CO}_{2}\right)$ from 0 to $100 \%$ vol.

The vertical oxidation profiles of methane $\left(\mathrm{Efv}_{\mathrm{ox}}\right)$ throughout the filter beds (as from the lower sampling port of the column) were given by Equation 1:

$$
\mathrm{Efv}_{0 \mathrm{x}}=\sum_{\mathrm{n}=1}^{5} \frac{\left(\mathrm{C}_{\mathrm{n}}-C_{\mathrm{n}+1}\right)}{\mathrm{C}_{\mathrm{n}}} \times 100(\%)
$$

where: $C_{\mathrm{n}}$ : methane concentration in a sampling port " $\mathrm{n}$ ", \%

$$
C_{\mathrm{n}+1} \text { : methane concentration in the sampling port immediately above it, \% }
$$

The overall oxidation efficiency of methane $\left(\mathrm{Efg}_{\mathrm{ox}}\right)$ in the biofilters only considered the methane concentrations in the gaseous stream at the entrance and exit (Equation 2) [36].

$$
\operatorname{Efg}_{0 \mathrm{x}}=\frac{\left(\mathrm{C}_{\left.\mathrm{i}-\mathrm{C}_{\mathrm{cut}}\right)}\right)}{\mathrm{C}_{\mathrm{in}}} \times 100(\%)
$$

where: $C_{\text {in }}$ : the methane concentration at the bottom of the biofilter (raw biogas), \%

$$
C_{\text {out }}: \text { the methane concentration in the biofilter headspace, \% }
$$

\section{Statistical analysis}

The data obtained were evaluated using generalized linear regression models to determine whether the column packing material temperatures, air temperature, soil moisture content, methane concentration in the raw biogas and the enrichment of the column substrate ( $\mathrm{C} / \mathrm{N}$ ratio) significantly influenced the methane oxidation efficiency. The temperatures were evaluated separately using 3 models, one for each type of temperature measured, since the correlation between them violated one of the principals of multiple linear regression. The analysis of variance was used to validate the regression models. The means of significant categorical predictors were contrasted using the Tukey test, and a $5 \%$ level of significance was used for all analyses. The Gaussian assumption was checked by the Shapiro-Wilks test and variance homogeneity by the Fligner-Killeen test, and the result was expressed by the " $p$ " value (a value $<0.05$ indicates statistical difference). The analyses were applied using the RStudio software, version 4.0.2, MASS packets and Ime [49].

\section{Results And Discussion}


Figure 2 presents the overall oxidation efficiencies of methane, the methane concentrations in the raw biogas and the moisture contents in the control and enriched columns, for all the campaigns with loading rates $1\left(22 \mathrm{~g}_{\mathrm{CH} 4} \cdot \mathrm{m}^{-2} \cdot \mathrm{d}^{-1}\right)$ and $2\left(44 \mathrm{~g}_{\mathrm{CH} 4} \cdot \mathrm{m}^{-2} \cdot \mathrm{d}^{-1}\right)$.

The first 40 days of the experiments (with a loading rate of $\cong 22 \mathrm{~g}_{\mathrm{CH} 4} \cdot \mathrm{m}^{-2} \cdot \mathrm{d}^{-1}$ ) seem to have been sufficient for a suitable acclimatation of the methanotrophic population. Even the first campaigns with loading rate 1 showed methane removal efficiencies equivalent to those found after several months of monitoring. Figure 2 also shows that the methane oxidation efficiencies were greater in the enriched column $(p<0.01)$ for all the campaigns and with both loading rates $(p<0.01)$. For the campaigns with loading rate 1 , the mean methane oxidation efficiencies were $98.4 \%(S D= \pm 1.4)$ and $89.5 \%(S D= \pm 2.6)$; and for the campaigns with loading rate 2 , the mean methane oxidation efficiencies were $92.6 \%(S D= \pm 1.4)$ and $82.3 \%$ ( $S D= \pm 2.6$ ), for the enriched and control columns, respectively. In fact, landfill soils with higher organic matter contents are associated with relatively high methane oxidation efficiencies $[14,20,28]$.

As mentioned above, substrates rich in organic matter are an important source of carbon and nutrients for the metabolic kinetics. Table 2 shows the $\mathrm{C} / \mathrm{N}$ ratios and $\mathrm{pH}$ values of the packing materials used in the control and enriched columns.

Table 2

Initial and final characteristics of the packing materials used in the biofilters

\begin{tabular}{|lllll|}
\hline \multicolumn{4}{|c|}{ Column } \\
\hline & Control & \multicolumn{3}{c|}{ Enriched ${ }^{(1)}$} \\
\hline Parameter & Initial & Final & Initial & Final \\
\hline $\mathrm{C} / \mathrm{N}$ & 14.4 & 19.7 & 9.4 & 10.6 \\
\hline $\mathrm{pH}$ & 5.5 & 5.7 & 5.7 & 5.8 \\
\hline (1) According to Table 1, this composition only refers to the top $15 \mathrm{~cm}$ of the enriched bed. \\
\hline
\end{tabular}

In general, low $\mathrm{C} / \mathrm{N}$ values are associated with elevated methane oxidation rates due to the greater nutrient presence [18]. Taking the compost prepared by Bernal et al. [50] with seven organic waste mixtures (including sewage sludge) as the parameter, a $\mathrm{C} / \mathrm{N}$ ratio $\leq 12$ indicates a mature compost, and hence adequate for the organic amendment of soil. In the present study, there was a reduction in the proportion of $\mathrm{N}$ in relation to $\mathrm{C}$ from the start to the finish of the experiment in both columns, reflecting nutrient consumption during methane oxidation (Table 2). The difference was considerably greater in the control column (C/N from 14.4 to 19.7), well above the reference value (12). Since the entire carbon and nitrogen contents of the two biofilters evaluated were originally present in the landfill cover soil and SWWTP and there was no nutrient replacement during the experiment, the values showed evidence of a greater nitrogen deficit in the control column since the start of the experiment, which became more and more accentuated throughout the 13 months the biofilters were operated. In the case of the enriched columns, the greater nutrient demand by the methanotrophic community [18] was compensated by the higher $\mathrm{N}$ content present 
in the enriched portion of the enriched bed, which corroborated with the significantly higher methane oxidation efficiencies in this biofilter as compared to the control column $(p<0.01$, Fig. 2). It is thus clear that when dealing with organic packing materials, the nutrient content of the support medium must be frequently monitored [51] so as to guarantee their replacement during the operational phase of the biofilter and maintain an adequate $\mathrm{C} / \mathrm{N}$ ratio for the requirements of the methanotrophs.

Suitable $\mathrm{pH}$ values for methanotrophic activity are close to neutrality, but the $\mathrm{pH}$-range in the biofilters can vary considerably depending on the characteristics of the methanotrophic population, the type of packing material, the environmental conditions etc. $[18,19,33,51,52]$. On observing the slightly acid pH values reported in Table 2, it appears that this parameter did not influence the methane oxidation efficiency. For practically identical $\mathrm{pH}$ conditions in the two columns, the oxidation efficiencies in the enriched bed were close to $100 \%$ in all the campaigns of loading rate 1 . In fact, although tolerant of $\mathrm{pH}$ variations, it is fundamental for methanotrophs that the $\mathrm{pH}$ values of the medium remain constant throughout their biological activity $[25,33]$ as occurred in the present study.

Although both biofilters were watered in the same way throughout the monitoring period, the enriched column showed a higher moisture content throughout almost all the campaigns (Fig. 2), showing a greater water holding capacity (WHC) in this biofilter (at least in the upper portion of the bed, with its higher organic matter content). In fact, in addition to a greater water holding capacity, substrates with higher organic matter contents manage to retain the moisture content of the medium for a longer time [14]. Almost all the moisture contents were within the range of $\cong 50-55 \%$ (Fig. 2) for both columns and both loading rates. There is no consensus in the literature concerning an optimum moisture range for methane oxidation $[6,33$, $34]$ and these values can vary a lot as a function of the substrate characteristics $[19,53,54]$. However, the moisture values obtained corroborated with the reference range of $50-60 \%$ for most of the organic supports [55], and the slightly higher moisture contents obtained in the enriched column reflect greater methane oxidation microbial activity, since water is one of the $\mathrm{CH}_{4}$ oxidation products. Even though regularly trying to maintain the moisture content, this parameter varied considerably throughout the biofilter monitoring period, mainly due to the climatic conditions which dictated a greater or lesser drying of the upper portion of the filter beds. Nevertheless, considering that this was a field experiment under real conditions, the fluctuations in moisture content observed during the months of monitoring were acceptable. It is important to mention that the variation in moisture content during the campaigns did not significantly affect methane oxidation $(p=0.54)$ and the parameter of moisture did not show a significant coefficient on the model generated, demonstrating that the moisture control carried out during the experiment was efficient.

Duplication of the biogas inlet loading rate caused the mean methane oxidation efficiencies to fall $6.0 \%$ in the enriched column and $8.0 \%$ in the control column. The relationship between methane removal efficiency and the inlet loading rate and inlet $\mathrm{CH}_{4}$ concentration during biotreatment processes has been the subject of several studies [56-59], An increase in loading rate (or gas flow rate) generally increases the velocity with which the gas passes through the filter bed, thus reducing the residence time of the contaminant in the biofilter. At first, an increase in loading rate increases the transfer rate of the substrate (contaminant) present in the gaseous phase (bulk) to the biofilm, where the microorganisms grow and degrade the 
contaminant. However, as the biogas loading rate or even the contaminant concentration in the bulk continue increasing, there is a tendency for the methane conversion rate to decrease, since the mass transfer of this compound to the biofilm becomes the rate limiting step of the process. In addition, the mass transfer of methane at the gas-liquid interface is also affected by the low solubility of methane in the aqueous medium $[23,51,53,58,60]$. Thus, even though the maximum loading rates reported in the literature (and hence the biotreatment efficiency) may vary considerably as a function of the system characteristics and operational conditions $[6,57,61,62]$, reduced loading rates (or elevated residence times) can favour methane oxidation in bio-based cover systems [18,35], as observed in the present study. The parameter "loading rate" was also significant for methane oxidation efficiency, and for loading rate 1 the mean efficiencies were indeed statistically higher than for loading rate 2 , for both the enriched and control columns (Table 3).

Table 3

Contrasts calculated by Tukey's test at $5 \%$ significance between the mean oxidation efficiencies of the biofilters and the loading rates

\begin{tabular}{|lll|}
\hline Loading rates & Biofilters & Efgox (average) \\
\hline 2 & Control & $82.3^{\mathrm{d}}$ \\
\hline 1 & Control & $89.5^{\mathrm{c}}$ \\
\hline 2 & Enriched & $92.6^{\mathrm{b}}$ \\
\hline $\begin{array}{l}\text { Means followed by the same letter do not differ significantly according to Tukey's test at } 5 \% \\
\text { significance. }\end{array}$ & Enriched \\
\hline
\end{tabular}

The methane concentrations in the raw biogas throughout the 25 campaigns of the experiment varied from 39.9 to $43.6 \%$ for loading rate 1 and from 39.3 to $43.1 \%$ for loading rate 2 (Fig. 2). The concentrations of the principal components of the LFG can vary temporally and spatially as a function of parameters such as the moisture content, temperature, $\mathrm{pH}$ value, nutrient availability in the waste mass, landfilling conditions, waste composition, decomposition phase of the residue and even the climatic conditions $[63,64,65]$. However, this fluctuation in the $\mathrm{CH}_{4}$ concentrations was not sufficiently high to interfere with the biofilter operations (control and enriched), since no relationship was observed between the inlet $\mathrm{CH}_{4}$ concentration and its oxidation efficiency, independent of the column and loading rate. In fact the $\mathrm{CH}_{4}$ concentration did not present a statistically significant coefficient in the linear models generated $(p=0.51)$. Thus, under the conditions of the present study, the variations in loading rate presented a much greater influence on the methane oxidation efficiency than the variations in methane concentration.

For all the campaigns with both loading rates 1 and 2, Fig. 3 presents the overall oxidation efficiencies of methane on the control and enriched columns as a function of the packing materials $\left(T_{\text {soil }}\right)$ and environmental $\left(T_{\text {envir }}\right)$ temperatures. 
T1 and T2: Thermometers installed, respectively, 40 and $10 \mathrm{~cm}$ from the filter bed surface.

\section{C: Control column E: Enriched column}

Independent of the loading rate under evaluation, the temperatures of the two filter beds at $40 \mathrm{~cm}$ (T1) and $10 \mathrm{~cm}$ (T2) from the surface showed temperatures above the environmental temperatures in all the monitoring campaigns. In fact, the biological oxidation of methane is an exothermic reaction, liberating $\cong 211 \mathrm{kcal}$ per mol of oxidized methane $[25,59]$. According to Fig. 3 , when loading rate 2 was applied to the biofilters and the methanotrophic activity increased, higher temperatures were registered on the enriched column at $10 \mathrm{~cm}$ from the surface, where there was a greater amount of organic matter provided by the SWWTP. In addition, the heat of the raw biogas supplied to the two columns as from the vertical drain added to the exothermicity of the system, which can lead to a considerable increase in the filter bed temperature [6]. Many studies have indicated a strong correlation between oxidation efficiency and the temperature of the medium $[19,24,26,35,36]$. Most of these studies reported an increase in methane removal efficiency with increase in temperature of the medium, and, similarly, a reduction in removal efficiency with decrease in temperature, mentioning temperatures in the range from $25-35^{\circ} \mathrm{C}$ to obtain optimal methane oxidation efficiency in different soil types $[19,59]$. However, such behaviour cannot be considered as a general rule. Depending on the conditions of the study, one can obtain methane biooxidation efficiencies above $80 \%$, even at lower temperatures [37, 38]. In the present study, as shown in Fig. 3, even at filter bed temperatures below $20^{\circ} \mathrm{C}$, the methanotrophs maintained their biological activity, obtaining methane removal efficiencies equivalent to those registered at temperatures above $25^{\circ} \mathrm{C}$. The heat liberated during methanotrophic activity or even that provided by the raw biogas (as mentioned above), allow for a certain "independence" of the system in relation to eventual falls in temperature of the filter beds or even oscillations in the environmental temperature [25]. Also, according to Gebert et al. [13], the methanotrophic population can adapt to variations in the environmental temperature, including shifting the optimal temperature range for methane oxidation, guaranteeing the performance of the biofilter even under low environmental temperature conditions. In the present study, even using an ample environmental temperature range ( $\cong 11$ to $\left.30^{\circ} \mathrm{C}\right)$, all the overall oxidation efficiencies of methane on the enriched columns were above $97 \%$ for loading rate 1 and $90 \%$ for loading rate 2 , as evidence that the temperature did not constitute a limiting parameter in this biological process. It was verified statistically that neither of the temperatures evaluated (T1 and T2) on the two biofilters or even the environmental temperature, presented significant coefficients for the oxidation efficiency prediction models.

In general, the variables that significantly influenced the methane oxidation efficiency were the differences between the packing materials (enriched and control beds) and the loading rates (Fig. 4). These two predictive variables explained about $92 \%$ of the behaviour related to Efgox $\left(R_{2 a d j}=0.92\right)$ for the three regression models evaluated. Thus for the models T1, T2 and T environmental, the determination coefficients adjusted by the degrees of liberty $\left(R_{2 a d j}\right)$ presented no difference in value.

Figures 5 and 6 present, for loading rates 1 and 2 respectively, the vertical oxidation methane profiles $\left(\mathrm{Efv}_{\mathrm{ox}}\right)$ and the ratio between the carbon dioxide and methane concentrations $\left(\mathrm{CO}_{2}: \mathrm{CH}_{4}\right)$ throughout the 
filter beds. The values plotted are the means of the campaigns for loading rate 1 (13 campaigns) and 2 (12 campaigns).

The determination of the ratio between the carbon dioxide and methane concentrations $\left(\mathrm{CO}_{2}: \mathrm{CH}_{4}\right.$ ratio) allows one to identify the depth of the methane oxidation zone within the filter bed. In the case of an upward flow biofilter, the $\mathrm{CO}_{2}: \mathrm{CH}_{4}$ ratio tends to increase from bottom to top as a function of the gradual oxidation of methane to carbon dioxide. The analysis of the methane oxidation profile presupposes, for example, that all the $\mathrm{CH}_{4}$ is converted to $\mathrm{CO}_{2}$, that microbe respiration is negligible (all the $\mathrm{CO}_{2}$ measured coming exclusively from the oxidation of $\mathrm{CH}_{4}$ ), that the size of the methanotrophic community is stable and that the system operates under steady state conditions $[15,18,66]$.

Figures 5 and 6 revealed that the principal methane oxidation zones occurred in the upper $\cong 23 \mathrm{~cm}$ of the control bed and upper $\cong 40 \mathrm{~cm}$ of the enriched bed for loading rate 1 ; and in the upper $\cong 23 \mathrm{~cm}$ of both columns for loading rate 2 . Thus oxidation was more significant in a larger portion of the enriched bed as compared to the control bed. In addition to supplying the soil with nutrients, the addition of organic matter to the cover layer increased the porosity of the medium $[67,68]$, improving the availability of oxygen to the methanotrophs and making $\mathrm{CH}_{4}$ circulation through the filter bed easier $[14,15,20,29]$. The greater porosity of the medium guarantees a longer residence time of the gases in the packing material, corroborating with an increase in the methane oxidation rate in the biofilter [25]. Although the parameter "porosity" was not determined in the present study, the addition of SWWTP to the cover soil resulted in a coarser medium (Fig. 7), making the penetration of atmospheric air easier. Although the SWWTP was only added to the upper 15 $\mathrm{cm}$ of the bed, even the lower layers of the enriched column showed a slightly superior performance as compared to the control column in terms of methane oxidation capacity. Since moistening was always done at the top of the packing materials, part of the organic matter concentrated at the top of the column was carried down to the deeper zones of the enriched bed, improving the conditions for methanotrophic activity in this region of the bed.

\section{Conclusions}

This study evaluated the efficiencies of microbial methane oxidation in two biofilters under real field conditions at the Guarapuava landfill (Brazil). The packing material of one of the biofilters (control column) was conventional soil used in the landfill cover (originally with a low organic matter content, $\sim 0.5 \%$ ), while a $15 \mathrm{~cm}$ layer of the second biofilter (enriched column) was enriched with dried scum from a municipal wastewater treatment plant (SWWTP) to raise the organic matter content of the biofilter ( 4.5\%).

The mean methane oxidation efficiencies were $98.4 \%(n=13, S D= \pm 1.4)$ and $89.5 \%(n=13, S D=+2.6)$ on the enriched and control columns, respectively for a loading rate of $22 \mathrm{gCH}_{4} \cdot \mathrm{m}^{-2} \cdot \mathrm{d}^{-1}$. For a loading rate of $44 \mathrm{gCH}_{4} \cdot \mathrm{m}^{-2} \cdot \mathrm{d}^{-1}$ the mean oxidation efficiencies were $92.6 \%(\mathrm{n}=12, \mathrm{SD}= \pm 1.4$, enriched column $)$ and $82.3 \%(n=12, S D= \pm 2.6$, control column). Thus even on the control column with a lower organic matter content throughout the filter bed, efficiencies higher than $80 \%$ were obtained, confirming the potential of biofiltration as a tool for the mitigation of atmospheric $\mathrm{CH}_{4}$ emissions from landfills. 
The factors which most influenced (significantly) the methane oxidation efficiencies were the differences between the packing materials (enriched and control beds) and the loading rates. The mixture of SWWTP with the conventional cover soil provided more organic matter and nutrient $(\mathrm{N})$ for the methanotrophic activity of methane oxidation. It must be mentioned that the enriched column managed to maintain a $\mathrm{C} / \mathrm{N}$ ratio in the range of values typical of mature compost. In addition, although the SWWTP was only added to the upper $15 \mathrm{~cm}$ of the bed, the lower layers of the enriched bed also presented a performance superior to that of the control column in terms of methane oxidation capacity. With respect to the loading rates, the lower value of $22 \mathrm{gCH}_{4} \cdot \mathrm{m}^{-2} \cdot \mathrm{d}^{-1}$ when applied to the biofilters contributed to obtaining longer residence times of the gas on the biofilters and, consequently, greater $\mathrm{CH}_{4}$ oxidation efficiencies as compared to the loading rate of $44 \mathrm{gCH}_{4} \cdot \mathrm{m}^{-2} \cdot \mathrm{d}^{-1}$.

In the present study and for the loading rates tested, parameters such as $\mathrm{pH}$ value, the moisture contents of the packing materials and the temperatures did not significantly influence the $\mathrm{CH}_{4}$ oxidation efficiency values. In fact, during the 25 campaigns, the $\mathrm{pH}$ and moisture content conditions were adequate for methanotrophic activity. Both columns were equally watered to maintain the moisture continuous in the filter beds. With respect to the temperatures, it was shown that, statistically, no value measured (filter beds and environment) influenced the $\mathrm{CH}_{4}$ oxidation efficiencies. The enriched and control columns maintained elevated $\mathrm{CH}_{4}$ oxidation percentages even with temperature oscillations in the external environment and filter beds.

The use of waste materials with elevated organic matter contents for soil amendment has been shown to be a relatively cheap resource, easily applied to improve the landfill cover layers aimed at mitigating greenhouse gases. Due to the enormous differences in the conditions of each landfill (such as local climatic conditions, landfill operational conditions, type and age of the landfilled waste, collection or not of the biogas, etc), there can be no universal solution in terms of the technology to be applied to the oxidation of methane in the cover layers. Each reality must be evaluated, concomitantly considering the biotic systems and other alternatives to reduce the carbon footprints in the waste management sector, such as the energetic exploitation of the biogas, improvements in the recycling program etc., treatments which are still highly incipient in developing countries.

\section{Abbreviations}

GDL - gas distribution layer

GHG - greenhouse gases

MSW - municipal solid wastes

STP - standard temperature and pressure

SWWTp - scum from municipal wastewater treatment plant

LFG - landfill gas

Page 13/23 
LR - loading rate

WHC - water holding capacity

\section{Declarations}

The authors declare they have no conflicts of interest.

\section{Acknowledgements}

The authors are grateful to the Coordination for the Improvement of Higher Education Personnel (CAPES, Grant \#88881.030497/2013-01) and to the "Fundação Araucária do Paraná" (Call n 09/2016) for their financial support. They are also grateful to the Guarapuava City Hall (State of Parana, Brazil).

\section{References}

1. Albanna, M., Fernandes, L.: Effects of temperature, moisture content, and fertilizer addition on biological methane oxidation in landfill cover soils. J. Hazard Toxic Radioact. Waste (2009). https://doi.org/10.1061/(ASCE)1090-025X(2009)13:3(187)

2. United States Environmental Protection Agency - USEPA. Global Mitigation of Non- $\mathrm{CO}_{2}$ Greenhouse Gases: 2010-2030. EPA-430-R-13-011, Washington DC. (2013)

3. Maciel, F.J., Jucá, J.F.T.: Evaluation of landfill gas production and emissions in a MSW large-scale experimental cell in Brazil. Waste Manag. (2011). https://doi.org/10.1016/j.wasman.2011.01.030

4. United States Environmental Protection Agency - USEPA. Technical support document for the landfill sector: proposed rule for mandatory reporting of greenhouse gases. https://19january2017snapshot.epa.gov/sites/production/files/2015-07/documents/tsd_landfills_ epa_02_04_09_2.pdf (2009). Accessed 25 November 2020

5. United States Environmental Protection Agency - USEPA. Available and emerging technologies for reducing greenhouse gas emissions from municipal solid waste landfills. https://www.epa.gov/sites/production/files/2015-12/documents/landfills.pdf (2011). Accessed 26 November 2020

6. Cabral, A.R, Moreira, J.F.V., Jugnia, L.-B.: Biocover performance of landfill methane oxidation: experimental results. J. Environ. Eng. (2010). https://doi.org/10.1061/(ASCE)EE.1943-7870.0000182

7. Kormi, T., Mhadhebi, S., Bel Hadj Ali, N., Abichou, T., Green, R.: Estimation of fugitive landfill methane emissions using surface emission monitoring and Genetic Algorithms optimization. Waste Manag. (2018). https://doi.org/10.1016/j.wasman.2016.11.024

8. Mønster, J., Kjeldsen, P., Scheutz, C.: Methodologies for measuring fugitive methane emissions from landfills - A review. Waste Manag. (2019). https://doi.org/10.1016/j.wasman.2018.12.047

9. Rachor, I., Streese-Kleeberg, J., Gebert, J.: Spatial and temporal variability of gas emissions from old landfills. Proceedings Sardinia, Twelfth International Waste Management and Landfill Symposium, 
Cagliari, Italy. (2009)

10. Bogner, J., Meadows, M., Czepiel, P., Smith, K.: Fluxes of methane between landfills and the atmosphere: natural and engineered controls. Soil Use Manag. (1997). https://doi.org/10.1111/j.14752743.1997.tb00598.x

11. Gámez, A.F.C., Maroto, J.M.R., Pérez, I.V.: Quantification of methane emissions in a Mediterranean landfill (Southern Spain). A combination of flux chambers and geostatistical methods. Waste Manag. (2019). https://doi.org/10.1016/j.wasman.2018.12.015

12. Röwer, I.U., Geck, C., Gebert, J., Pfeiffer, E-M.: Spatial variability of soil gas concentration and methane oxidation capacity in landfill covers. Waste Manag. (2011). https://doi.org/10.1016/j.wasman.2010.09.013

13. Gebert, J., Groengroeft, A., Miehlich, G.: Kinetics of microbial landfill methane oxidation in biofilters. Waste Manag. (2003). https://doi.org/10.1016/S0956-053X(03)00105-3

14. Huber-Humer, M., Gebert, J., Hilger, H.: Biotic systems to mitigate landfill methane emissions. Waste Manag. Res. (2008). https://doi.org/10.1177/0734242X07087977

15. Kjeld, A.: Microbial methane oxidation at the Fíflholt landfill in Iceland. Thesis, Faculty of Civil and Environmental Engineering, University of Iceland, Reykjavik, Iceland. (2013)

16. Majdinasab, A., Yuan, Q.: Performance of the biotic systems for reducing methane emissions from landfill sites: A review. Ecol. Eng. (2017). https://doi.org/10.1016/j.ecoleng.2017.04.015

17. Menard, C., Ramirez, A.A., Nikiema, J., Heitz, M.: Biofiltration of methane and trace gases from landfills: a review. Environ. Rev. (2012). https://doi.org/10.1139/a11-022

18. Sadasivam, B.Y., Reddy, K.R.: Landfill methane oxidation in soil and bio-based cover systems: a review. Rev. Environ. Sci. Biotechnol. (2014). https://doi.org/10.1007/s11157-013-9325-z

19. Scheutz, C., Kjeldsen, P., Bogner, J.E., De Visscher, A., Gebert, J., Hilger, H.A., Huber-Humer, M., Spokas, K.: Microbial methane oxidation processes and technologies for mitigation of landfill gas emissions. Waste Manag. Res. (2009). https://doi.org/10.1177/0734242X09339325

20. Abushammala, M.F.M., Basri, N.E.A., Irwan, D., Younes, M.K.: Methane oxidation in landfill cover soils: a review. Asian J. Atmos. Environ. (2014). https://doi.org/10.5572/ajae.2014.8.1.001

21. IPCC: Climate Change 2007: Mitigation. Contribution of Working Group III to the Fourth Assessment Report of the Intergovernmental Panel on Climate Change. B. Metz, O.R. Davidson, P.R. Bosch, R. Dave, L.A. Meyer (eds.), Cambridge University Press, Cambridge, United Kingdom and New York. (2007)

22. Ahoughalandari, B., Cabral, A.R., Leroueil, S.: Elements of design of passive methane oxidation biosystems: fundamental and practical considerations about compaction and hydraulic characteristics on biogas migration. Geotech. Geol. Eng. (2018). https://doi.org/10.1007/s10706-018-0485-z

23. La, H., Hettiaratchi, J.P.A., Achari, G., Dunfield, P.F.: Biofiltration of methane. Bioresour. Technol. (2018). https://doi.org/10.1016/j.biortech.2018.07.043

24. Börjesson, G., Sundh, I., Svensson, B.: Microbial oxidation of $\mathrm{CH}_{4}$ at different temperatures in landfil cover soils. FEMS Microbiol. Ecol. (2004). https://doi.org/10.1016/j.femsec.2004.02.006 
25. Humer, M., Lechner, P.: Alternative approach to the elimination of greenhouse gases from old lanfills. Waste Manag. Res. (1999). https://doi.org/10.1177/0734242X9901700607

26. Lee, Y.-Y., Jung, H., Ryu, H.-W., Oh, K.-C., Jeon, J.-M., Cho, K.-S.: Seasonal characteristics of odor and methane mitigation and the bacterial community dynamics in an on-site biocover at a sanitary landfill. Waste Manag. (2018). https://doi.org/10.1016/j.wasman.2017.10.037

27. Ndanga, E.M., Bradley, R.L., Cabral, A.R.: Does vegetation affect the methane oxidation efficiency of passive biosystems ? Waste Manag. (2015). https://doi.org/10.1016/j.wasman.2015.01.031

28. Franqueto, R., Cabral, A.R., Capanema, M.A., Schirmer, W. N.: Fugitive methane emissions from two experimental biocovers constructed with tropical residual soils: field study using a large flux chamber. Detritus (2019). https://doi.org/10.31025/2611-4135/2019.13844

29. Kettunen, R.H., Einola, J-K. M., Rintala, J.A.: Landfill methane oxidation in engineered soil columns at low temperature. Water Air Soil Pollut. (2006). https://doi.org/10.1007/s11270-006-9176-0

30. Pariatamby, A., Cheah, W.Y., Shrizal, R., Thamlarson, N., Lim, B.T., Barasarathi, J.: Enhancement of landfill methane oxidation using different types of organic wastes. (2015). https://doi.org/10.1007/s12665-014-3600-3

31. Van Lith, C., Leson, G., Michelsen, R.: Evaluating design options for biofilters. J. Air Waste Manag. (1997). https://doi.org/10.1080/10473289.1997.10464410

32. Bender, M., Conrad, R.: Effect of $\mathrm{CH}_{4}$, concentrations and soil conditions on the induction of $\mathrm{CH}_{4}$, oxidation activity. Soil Biol. Biochem. (1995). https://doi.org/10.1016/0038-0717(95)00104-M

33. Huber-Humer, M., Röder, S., Lechner, P.: Approaches to assess biocover performance on landfills. Waste Manag. (2009). https://doi.org/10.1016/j.wasman.2009.02.001

34. Shangari, G.S., Agamuthu, P.: Enhancing methane oxidation in landfill cover using brewery spent grain as Biocover. Malaysian J. Sci. (2012). https://doi.org/10.22452/mjs.vol31no2.8

35. Capanema, M.A., Cabral, A.R.: Evaluating methane oxidation efficiencies in experimental landfill biocovers by mass balance and carbon stable isotopes. Water Air Soil Pollut. (2012). https://doi.org/10.1007/s11270-012-1302-636.

36. Fedrizzi, F., Cabana, H., Ndanga, É.M., Cabral, A.R.: Biofiltration of methane from cow barns: Effects of climatic conditions and packing bed media acclimatization. Waste Manag. (2018). https://doi.org/10.1016/j.wasman.2018.06.03837.

37. Berger, J., Fornés, L.V., Ott, C., Jager, J., Wawra, B., Zanke, U.: Methane oxidation in a landfill cover with capillary barrier. Waste Manag. (2005). https://doi.org/10.1016/j.wasman.2005.02.005

38. Scheutz, C., Pedersen, R.B., Petersen, P.H., Jørgensen, J.H.B., Ucendo, I.M.B., Mønster, J.G., Samuelsson, J., Kjeldsen, P.: Mitigation of methane emission from an old unlined landfill in Klintholm, Denmark using a passive biocover system. Waste Manag. (2014). https://doi.org/10.1016/j.wasman.2014.03.015

39. Fiuza, T.E.R., Souza, E.C.F., Antunes, S.R.M., Costa, W., Arrúa, M.E.P., Antunes, A.C.: Avaliação da utilização das cinzas da escuma gerada em reator anaeróbico de manta de lodo e fluxo ascendente 
como pigmento inorgânico de coloração alaranjada. Eng. Sanit. Ambient. (2017). https://doi.org/10.1590/S1413-41522017158707

40. Von Sperling, M.: Overview of sludge treatment and disposal (Ch. 05). In: Wastewater characteristics, Treatment and Disposal. IWA Publishing, London (2007)

41. Guarapuava: Plano municipal de saneamento básico - Município de Guarapuava-PR: diagnóstico e plano de metas. http://www.concidade.com.br/concidade/download /planos_municipais/Plano_Municipal_de_Saneamento_Guarapuava_2018_2021_versao_audiencia.pdf (2017). Accessed 08 January 2020 [in Portuguese]

42. Brazilian Institute of Geography and Statistics - IBGE: Cities and States - Guarapuava. https://www.ibge.gov.br/en/cities-and-states/pr/guarapuava.html (2020). Accessed 09 December 2020

43. Instituto de Desenvolvimento Rural do Paraná (IDR): Solicitação de dados meteorológicos UNICENTRO [personal message] Received by <sam@idr.pr.gov.br> on 10 June 2020 [in Portuguese]

44. Cantarella, H., Quaggio, J.A., Raij, B.V.: Determinação de matéria orgânica. In: Raij B.V., Andrade, J.C., Cantarella, H., Quaggio, J.A.: Análise Química para Avaliação da Fertilidade de Solos Tropicais. Instituto Agronômico, Campinas (2001) [in Portuguese]

45. Walkley A., Black, I.A.: An examination of the Degtjareff method for determining soil organic matter and a proposed modification of the chromic acid titration method. Soil Sci. (1934). https://doi.org/10.1097/00010694-193401000-00003

46. Cantarella, H., Trivelin, P.C.O.: Determinação de nitrogênio total em solo. In: Raij B.V., Andrade J.C., Cantarella, H., Quaggio, J.A.: Análise Química para Avaliação da Fertilidade de Solos Tropicais. Instituto Agronômico, Campinas (2001) [in Portuguese]

47. Quaggio, J.A., Raij, B.V.: Determinação do pH em cloreto de cálcio e da acidez total. In: Raij, B.V., Andrade, J.C., Cantarella, H., Quaggio, J.A.: Análise Química para Avaliação da Fertilidade de Solos Tropicais. Instituto Agronômico, Campinas (2001) [in Portuguese]

48. Ross, B.Z.L.: Escuma de reatores anaeróbios tratando esgotos domésticos em escala real: produção, caracterização e proposição de parâmetros para seu gerenciamento. Thesis, Postgraduate Program in Water Resources and Environmental Engineering, Federal University of Paraná, Curitiba, Brazil. (2015) [in Portuguese]

49. RStudio Team: RStudio. Integrated Development for R. RStudio, PBC, Boston, MA. http://www.rstudio.com/ (2020)

50. Bernal, M.P., Paredes, C., Sánchez-Monedero, M.A., Cegarra, J.: Maturity and stability parameters of composts prepared with a wide range of organic wastes. Bioresour. Technol. (1998) https://doi.org/10.1016/S0960-8524(97)00084-9

51. Devinny, J.S., Deshusses, M.A., Webster, T.S.: Biofiltration for Air Pollution Control. CRC Lewis Publishers, Boca Raton (1999)

52. Han, J-S., Mahanty, B., Yoon, S-U., Kim, C-G.: Activity of a methanotrophic consortium isolated from landfill cover soil: response to temperature, $\mathrm{pH}, \mathrm{CO}_{2}$, and porous adsorbent. Geomicrobiol. J. (2016). 
https://doi.org/10.1080/01490451.2015.1123330

53. Huang, Q., Zhang, Q., Cicek, N., Mann, D.: Biofilter: A promising tool for mitigating methane emission from manure storage. J. Arid Land (2011). https://doi.org/10.3724/SP.J.1227.2011.00061

54. Rose, J.L., Mahler, C.F., Izzo, R.L.S.: Comparison of the methane oxidation rate in four media. Rev. Bras. Ciênc. Solo (2012). https://doi.org/10.1590/S0100-06832012000300011

55. Bohn, H.L., Bohn, K.H.: Moisture in biofilters. Environ. Prog. (1999). https://doi.org/10.1002/ep.670180311

56. Brandt, E.M.F., Duarte, F.V., Vieira, J.P.R., Melo, V.M., Souza, C.L., Araújo, J.C., Chernicharo, C.A.L.: The use of novel packing material for improving methane oxidation in biofilters. J. Environ. Manag. (2016). https://doi.org/10.1016/j.jenvman.2016.07.075

57. Ferdowsi, M., Veillette, M., Ramirez, A.A., Jones, J.P., Heitz, M.: Performance Evaluation of a Methane Biofilter Under Steady State, Transient State and Starvation Conditions. Water Air Soil Pollut. (2016). https://doi.org/10.1007/s11270-016-2838-7

58. Nikiema, J., Heitz, M.: The influence of the gas flow rate during methane biofiltration on an inorganic packing material. Can. J. Chem. Eng. (2009). https://doi.org/10.1002/cjce.20131

59. Park, S., Lee, C-H., Ryu, C-R., Sung, K.: Biofiltration for reducing methane emissions from modern sanitary landfills at the low methane generation stage. Water Air Soil Pollut. (2009). https://doi.org/10.1007/s11270-008-9754-4

60. Kraakman, N.J.R., Rocha-Rios, J., Van Loosdrecht, M.C.M.: Review of mass transfer aspects for biological gas treatment. Appl. Microbiol. Biotechnol. (2011). https://doi.org/10.1007/s00253-0113365-5

61. Einola, J-K. M., Karhu, A.E., Rintala, J.A.: Mechanically-biologically treated municipal solid waste as a support medium for microbial methane oxidation to mitigate landfill greenhouse emissions. Waste Manag. (2008). https://doi.org/10.1016/j.wasman.2007.01.002

62. Mei, C., Yazdani, R., Han, B.; Mostafid, M.E., Chanton, J., VanderGheynst, J., Imhoff, P.: Performance of green waste biocovers for enhancing methane oxidation. Waste Manag. (2015).

https://doi.org/10.1016/j.wasman.2015.01.042

63. Cooper, C.D., Reinhart, D.R., Rash, F., Seligman, D., Keely, D.: Landfill gas emissions. Report \#92-2. Civil and Environmental Engineering Department. University of Central Florida, Orlando, Florida (USA). (1992)

64. Eklund, B., Anderson, E.P., Walker, B.L., Burrows, D.B.: Characterization of landfill gas composition at the fresh kills municipal solid-waste landfill. Environ. Sci. Technol. (1998). https://doi.org/10.1021/es980004s

65. Rasi, S., Läntelä, J., Rintala, J.: Trace compounds affecting biogas energy utilisation - A review. Energy Convers. Manag. (2011). https://doi.org/10.1016/j.enconman.2011.07.005

66. Gebert, J., Röwer, I.U., Scharff, H., Roncato, C.D.L., Cabral, A.R.: Can soil gas profiles be used to assess microbial $\mathrm{CH}_{4}$ oxidation in landfill covers ? Waste Manag. (2011). https://doi.org/10.1016/j.wasman.2010.10.008 
67. Ait-Benichou, S.; Jugnia, L-B.; Greer, C.W.; Cabral, A.R.: Methanotrophs and methanotrophic activity in engineered landfill biocovers. Waste Manag. (2009). https://doi.org/10.1016/j.wasman.2009.05.005

68. Czepiel, P.M., Crill, P.M., Harriss, R.C.: Environmental factors influencing the variability of methane oxidation in temperate zone soils. J. Geophys. Res. (1995). https://doi.org/10.1029/95JD00542

\section{Figures}

\section{ENRICHED COLUMN}

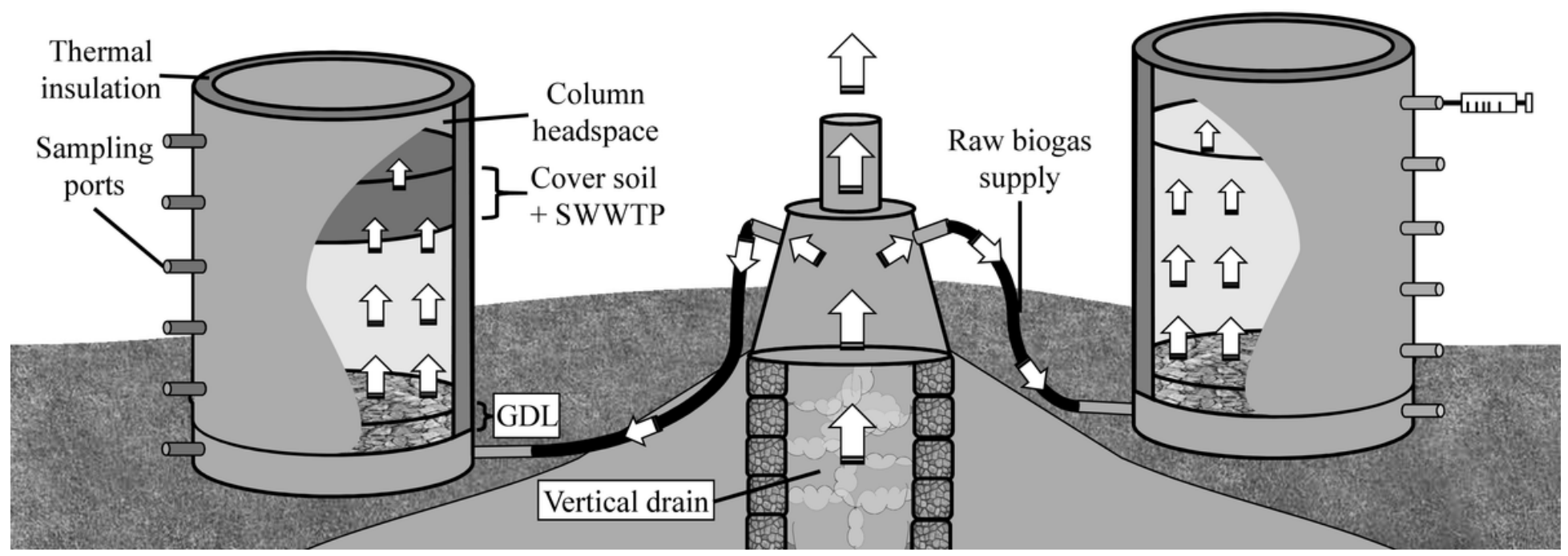

Figure 1

Experimental design of the field biofilters

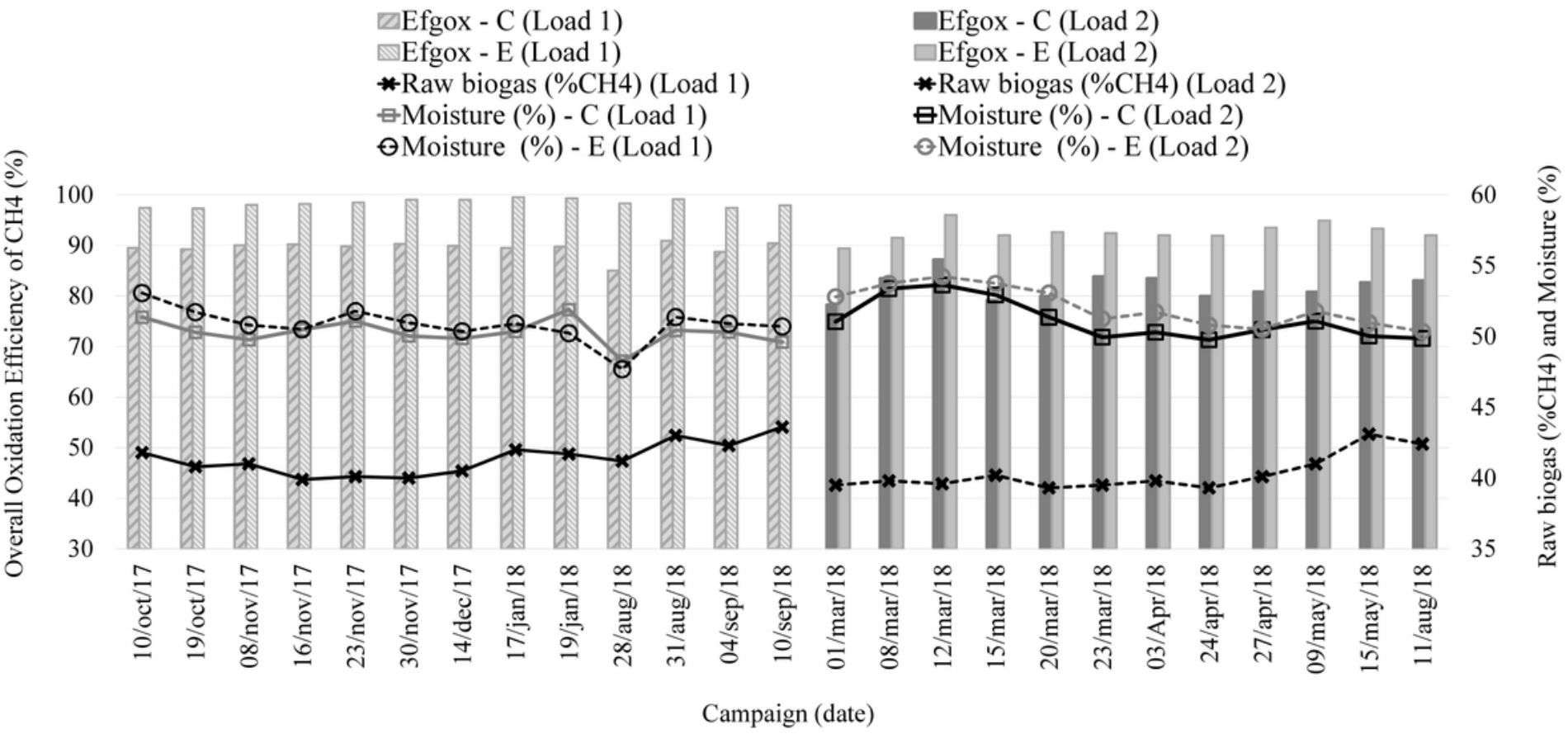

Figure 2 
Oxidation efficiencies, \% $\mathrm{CH} 4$ in the raw biogas and the moisture contents in the control (C) and enriched (E) columns for loading rates 1 and 2

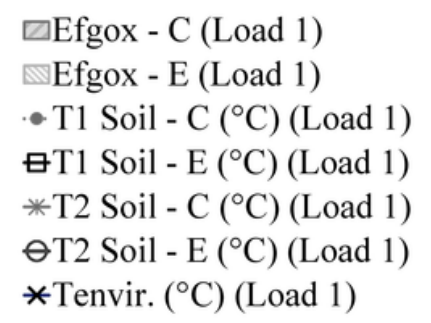

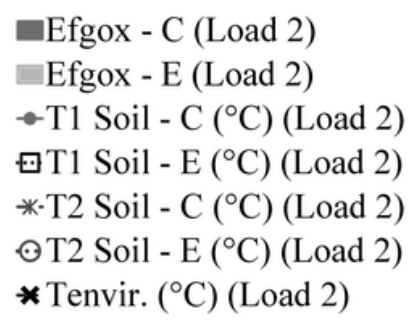

Efgox - C (Load 2)

Efgox - E (Load 2)

$\rightarrow \mathrm{T} 1$ Soil - C $\left({ }^{\circ} \mathrm{C}\right)(\operatorname{Load} 2)$

$\boxplus$ T1 Soil - E $\left({ }^{\circ} \mathrm{C}\right)($ Load 2$)$

*-T2 Soil - C $\left({ }^{\circ} \mathrm{C}\right)(\operatorname{Load} 2)$

* Tenvir. $\left({ }^{\circ} \mathrm{C}\right)(\operatorname{Load} 2)$

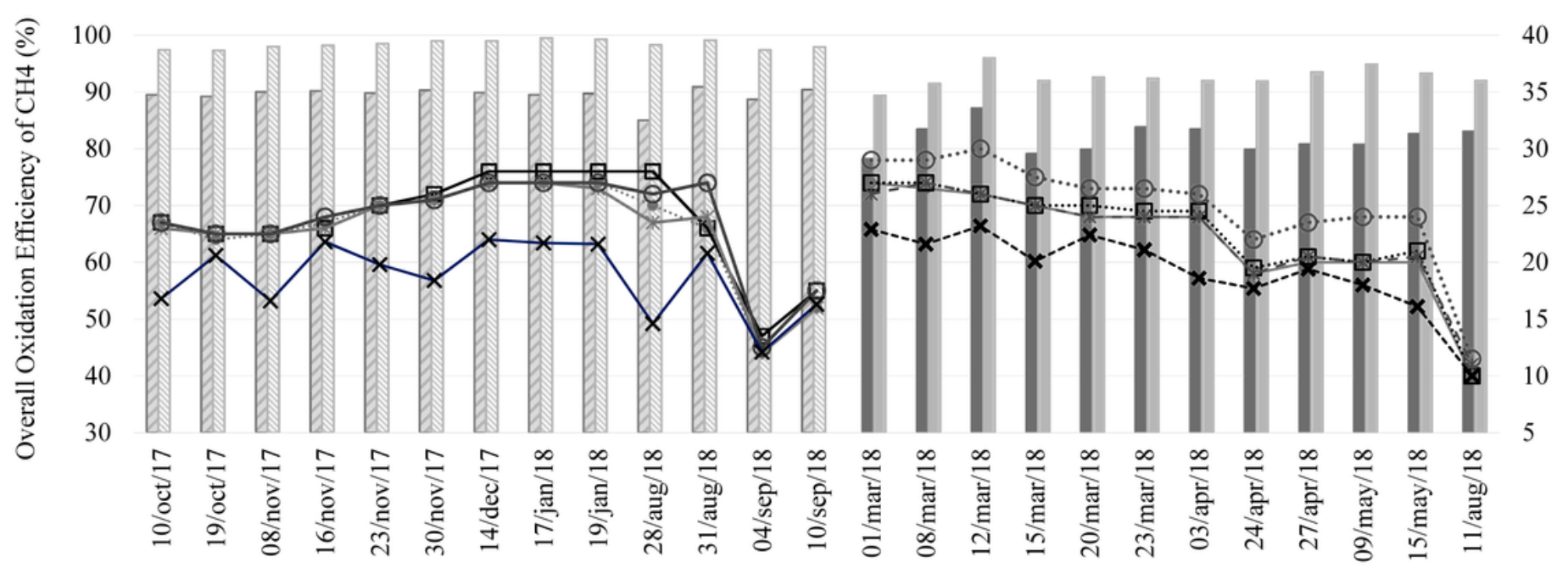

Campaign (date)

\section{Figure 3}

Oxidation efficiencies, environmental temperatures and the temperatures of the packing materials of the control and enriched columns for both loading rates 1 and 2 


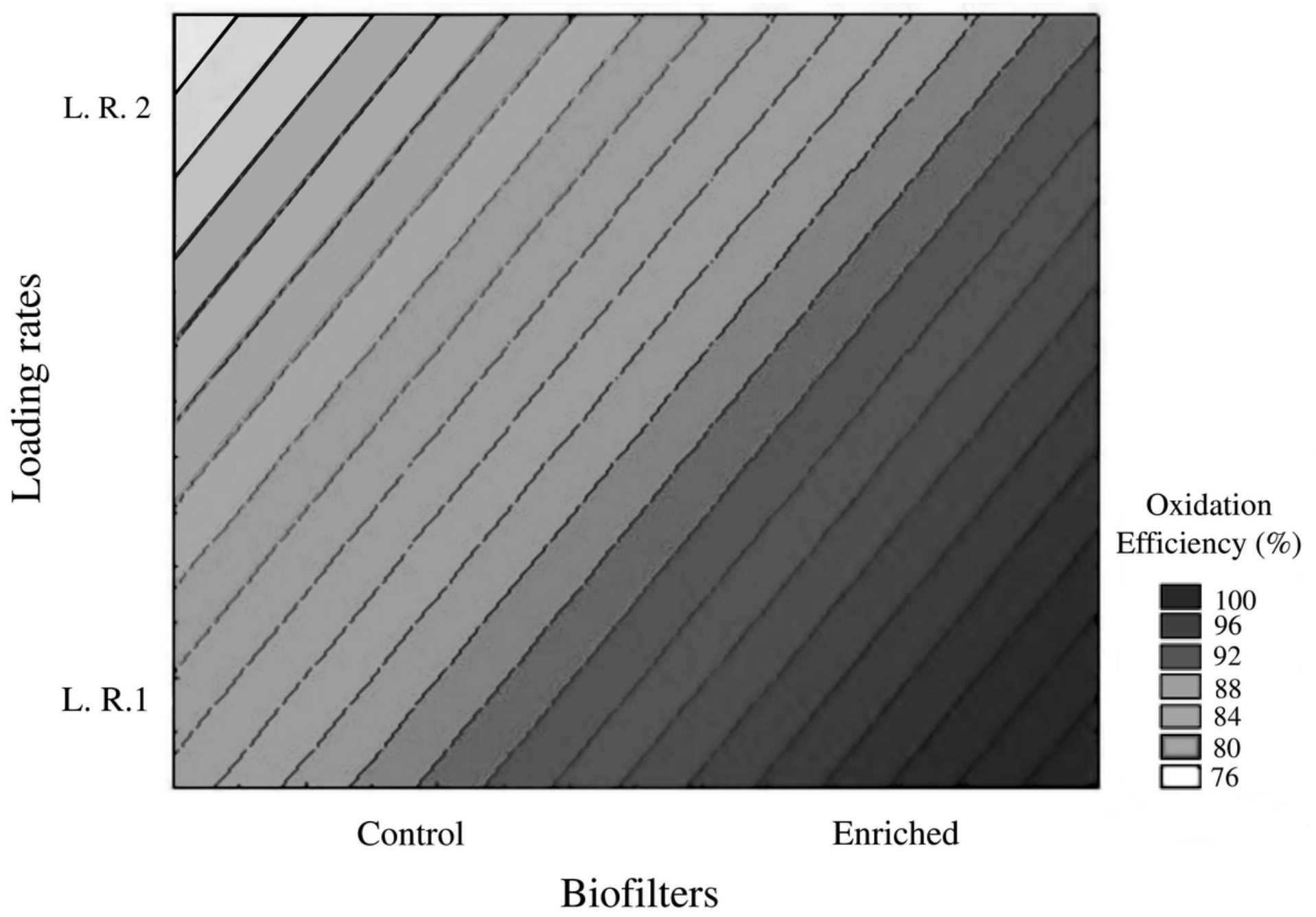

\section{Figure 4}

Response surface generated between the predictive variables "loading rates (LR)" and "biofilters" as a function of the predictive Efgox. Significant model $\left(p<0.01\right.$, Efgox $\left.=265.122+8.9077^{\star} x-5.5733^{*} y\right)$ 


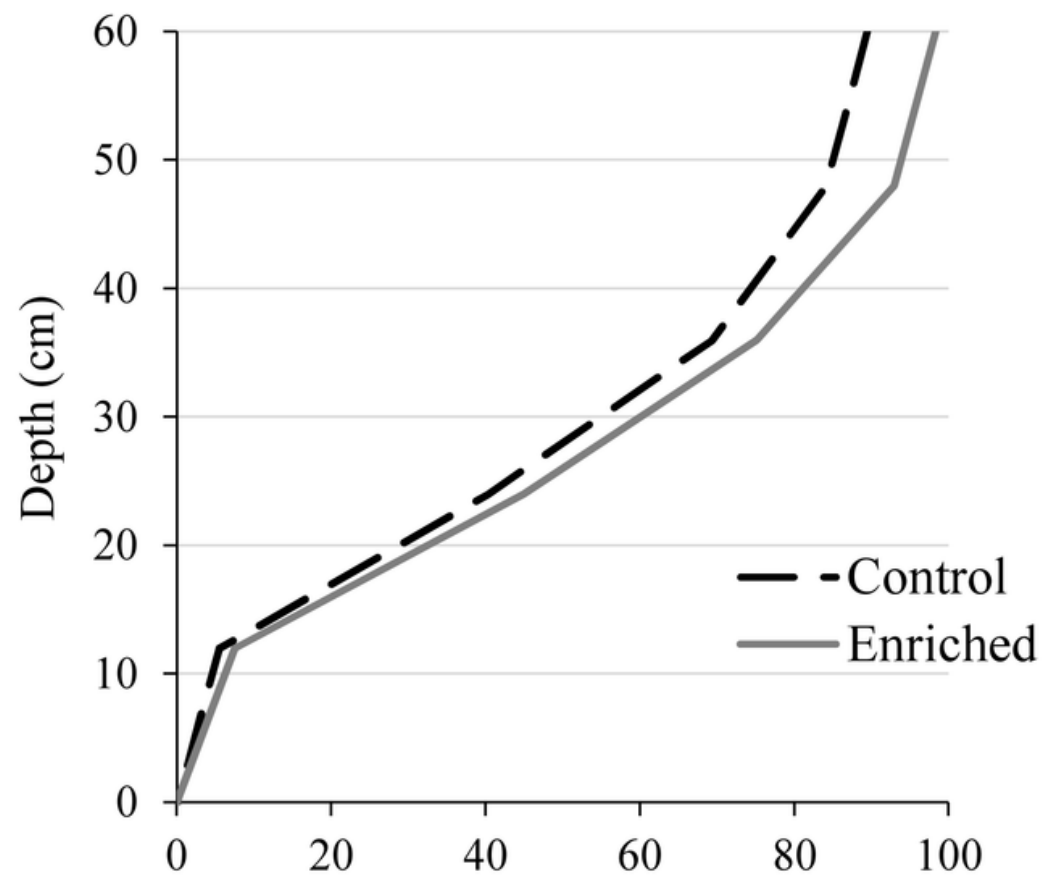

Average Oxidation Efficiency of $\mathrm{CH}_{4}(\%)$

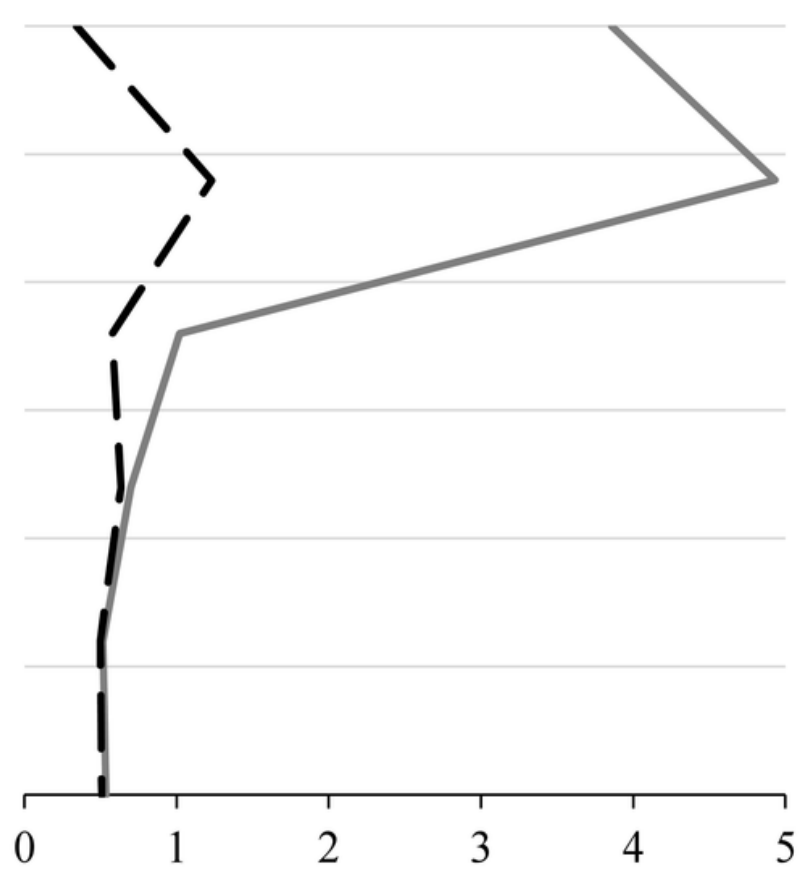

$\mathrm{CO}_{2} / \mathrm{CH}_{4}$ ratio

Figure 5

Average oxidation efficiencies of $\mathrm{CH} 4, \mathrm{CO} 2 \mathrm{CH} 4$ ratios and the $\mathrm{CH} 4$ concentrations (vertical profiles) of the control and enriched columns for loading rate 1

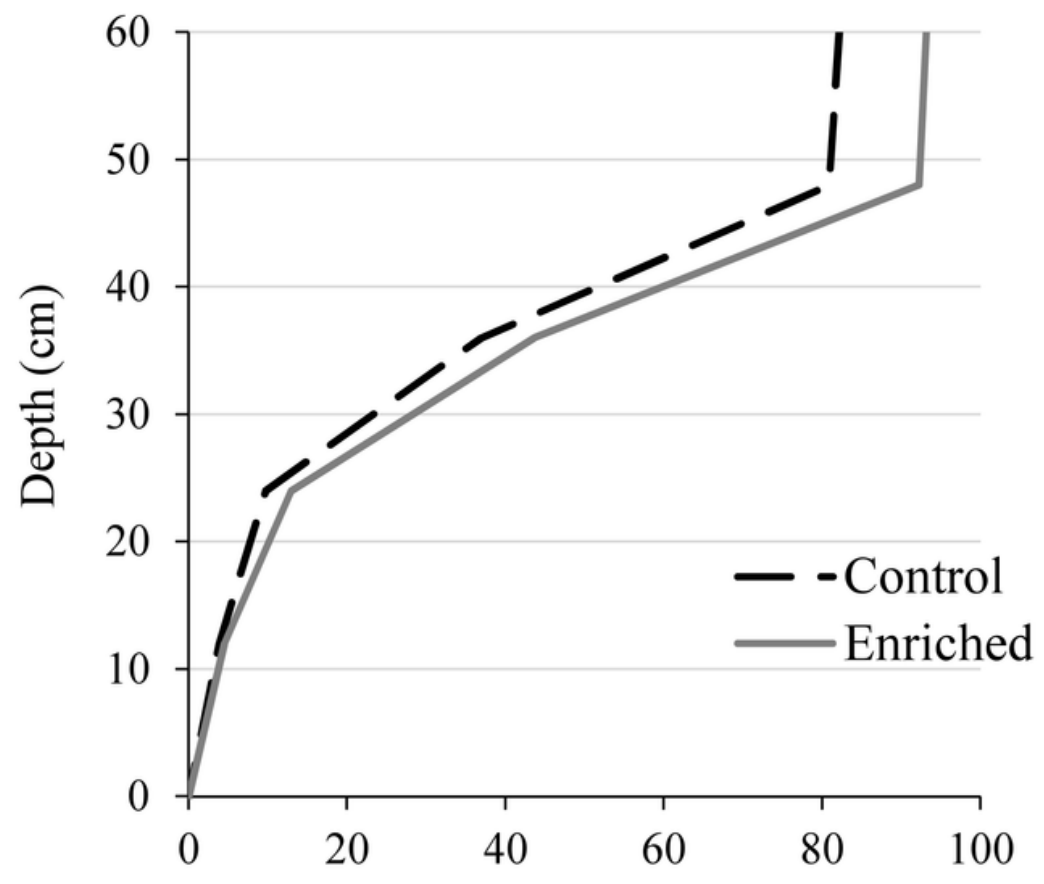

Average Oxidation Efficiency of $\mathrm{CH}_{4}(\%)$

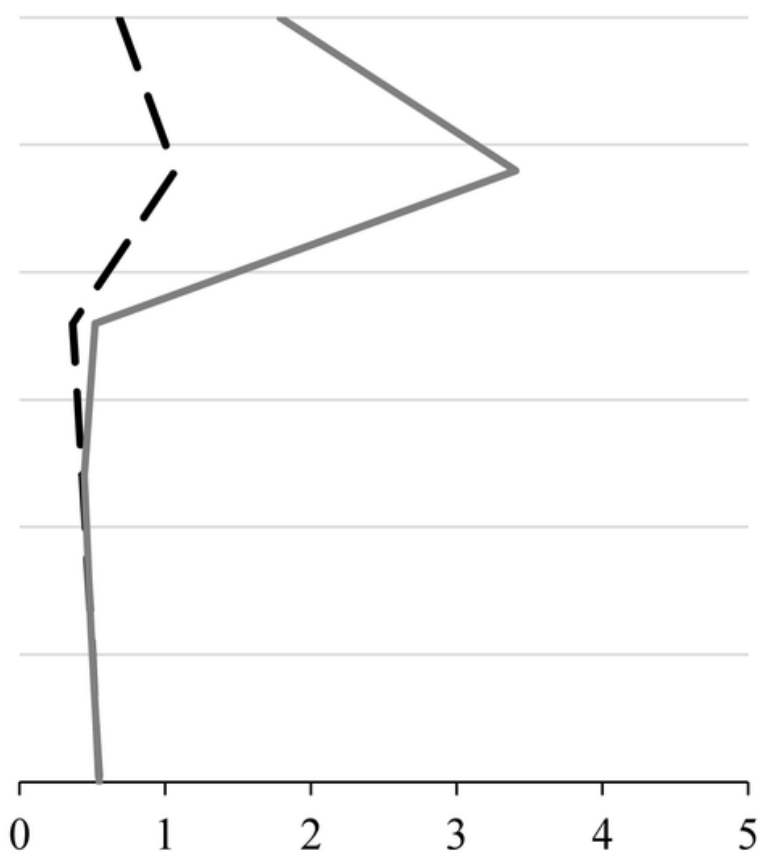

$\mathrm{CO}_{2} / \mathrm{CH}_{4}$ ratio

Figure 6 
Average oxidation efficiencies of $\mathrm{CH} 4, \mathrm{CO} 2: \mathrm{CH} 4$ ratios and the $\mathrm{CH} 4$ concentrations (vertical profiles) of the control and enriched columns for loading rate 2

(a)

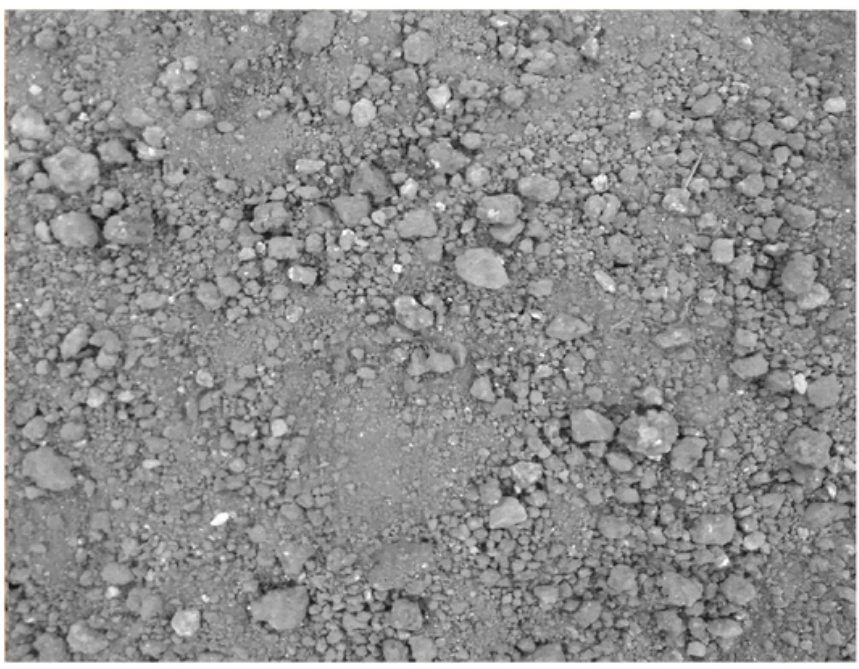

(b)

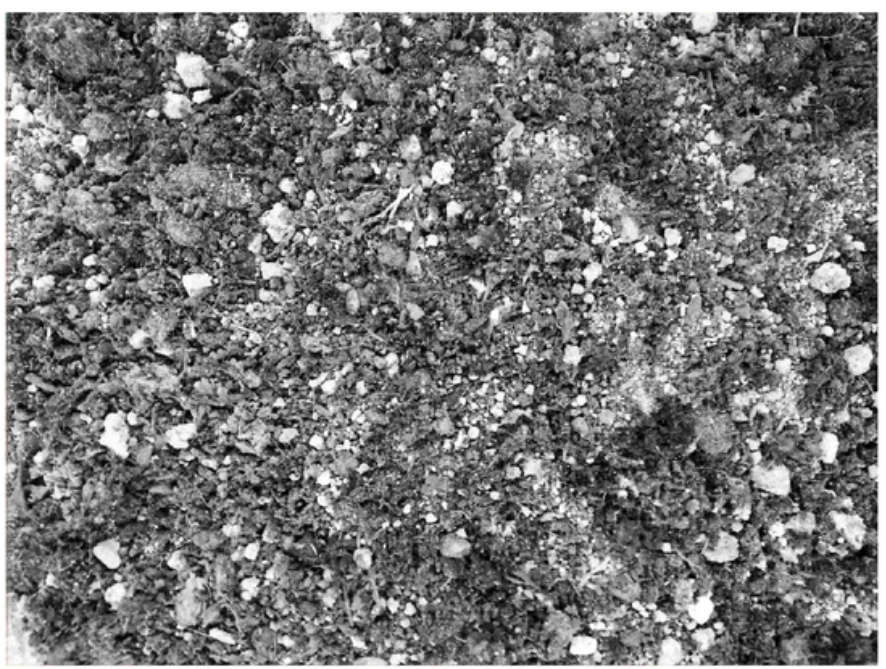

Figure 7

Packing material: (a) Control column (only cover soil); (b) Enriched column (soil cover + SWWTP)

\section{Supplementary Files}

This is a list of supplementary files associated with this preprint. Click to download.

- GraphAbstract.tiff 